\title{
Being a nurse, being a counselor: awakening to social control and public health
}

\author{
Ser enfermeiro, ser conselheiro: despertando para o controle social e saúde pública \\ Ser enfermero, ser consejero: despertando para el control social y salud pública
}

Hermínia Maria Sousa da Ponte' ORCID: 0000-0002-4652-2950

Antônio Vicente Júnior Gonçalves Silva" ORCID: 0000-0002-5084-4856

Francisco Ricardo Miranda Pinto"'I ORCID: 0000-0003-0771-6266

Francisca Alanny Rocha Aguiariv ORCID: 0000-0002-6281-4523

Ana Laura Mendonça de Aviz ${ }^{v}$ ORCID: 0000-0003-0211-5963

Samia Freitas Aires' ORCID: 0000-0003-1781-6623

\section{Carlos Henrique do Nascimento Morais ${ }^{\prime v}$} ORCID: 0000-0002-8915-8714

Francisco Meykel Amâncio Gomes ${ }^{1 \mathrm{~V}}$ ORCID: 0000-0002-5144-8978

' Universidade Estadual do Ceará. Fortaleza, Ceará, Brazil. "Catunda City Hall. Catunda, Ceará, Brazil. I" Universidade Estadual Vale do Acaraú. Sobral, Ceará, Brazil. "Instituto Superior de Teologia Aplicada. Sobral, Ceará, Brazil. $\checkmark$ Jijoca de Jericoacoara City Hall. Jijoca de Jericoacoara,

Ceará, Brazil.

How to cite this article:

Ponte HMS, Silva AVJG, Pinto FRM, Aguiar FAR, Aviz ALM, Aires $S F$, et al. Being a nurse, being a counselor: awakening to social control and public health.

Rev Bras Enferm [Internet]. 2019;72(1):134-9. DOI: http://dx.doi.org/10.1590/0034-7167-2017-0544

Corresponding Author:

Hermínia Maria Sousa Ponte

E-mail: herminiamponte@gmail.com

Submission: 07-28-2017

Approval: 07-28-2018

\section{ABSTRACT}

Objective: Understand the time of awakening to social control and its contributions from the perspective of health counselor nurses. Method: Semi-structured interviews were conducted with eight nurses who work/worked as health counselors. The information was analyzed using the thematic analysis of Minayo. Results: The interest in participating in the council emerged from the professionalization in the Family Health Strategy, whether in the continuation of the Municipal Council of Health, in the training, or in the participation in the student movement. The contributions included the development of a critical and reflective spirit, better understanding of health system management, increased sensitivity to the needs of the user, and close relationship with the community. Final Considerations: Despite some deficiencies and misconceptions of nurses, it is believed that nursing is on the right track in the defense and construction of a societarian project.

Descriptors: Health Planning Councils; Social Control Policies; Unified Health System; Social Participation; Nursing.

\section{RESUMO}

Objetivo: Compreender o momento do despertar para o controle social e suas contribuições sob a ótica de enfermeiros conselheiros de saúde. Método: Realizouse entrevista semiestruturada com oito enfermeiros que atuam/atuaram como conselheiros de saúde. As informações foram analisadas por meio da análise temática de Minayo. Resultados: $O$ interesse em participar do conselho emergiu a partir da profissionalização na Estratégia Saúde da Família, seja no prosseguimento do Conselho Municipal de Saúde, na formação ou na participação no movimento estudantil. Entre as contribuições relatou-se a formação de um espírito crítico e reflexivo, melhor compreensão da gestão do sistema de saúde, aumento da sensibilidade com as necessidades do usuário e aproximação com a comunidade. Considerações finais: Apesar de algumas fragilidades e concepções equivocadas dos enfermeiros, acreditase que a enfermagem está no caminho certo na defesa e construção de um projeto societário.

Descritores: Conselhos de Saúde; Políticas de Controle Social; Sistema Único de Saúde; Participação Social; Enfermagem.

\section{RESUMEN}

Objetivo: Comprender el momento del despertar para el control social y sus contribuciones bajo la óptica de enfermeros consejeros de salud. Método: Se realizó una entrevista semiestructurada con ocho enfermeros que actúan/actuaron como consejeros de salud. Se analizaron las informaciones por medio del análisis temático de Minayo. Resultados: El interés en participar del consejo surgió a partir de la profesionalización en la Estrategia Salud de la Familia, ya sea en la prosecución del Consejo Municipal de Salud, en la formación, o sea en la participación en el movimiento estudiantil. Entre las contribuciones, se relató la formación de un espíritu crítico y reflexivo, mejor comprensión de la gestión del sistema de salud, aumento de la sensibilidad con las necesidades del usuario y acercamiento a la comunidad. Consideraciones finales: $\mathrm{A}$ pesar de algunas fragilidades $\mathrm{y}$ concepciones equivocadas de los enfermeros, se cree que la enfermería está en el camino correcto en la defensa y construcción de un proyecto societario.

Descriptores: Consejos de Salud; Políticas de Control Social; Sistema Único de Salud; Participación Social; Enfermería. 


\section{INTRODUCTION}

The movement to build health as a social right had the participation of several actors united in the Brazilian Health Reform movement, which presents its greatest expression in the 8th National Conference on Health, which brought in its theme Democracy and Health and had, for the first time in its history, the participation of workers and the population.

Founding the new democratic paths to health through the Federal Constitution of 1988, with the creation of the Brazilian Unified Health System (SUS), which formally established principles and guidelines of universality, integrality, social participation and control $^{(1)}$, social participation in health was defined as a set of social forces and interventions for the formulation, evaluation and execution of public policies in this segment. Its institutionalization occurred through Organic Law no. 8,142/90, which regulates the parity of Social Participation as 50\% users, $25 \%$ private providers/ administrators, and $25 \%$ health professionals ${ }^{(2)}$.

Founded on this legal framework, the 1990s was marked by the dissemination of health councils in several municipalities by institutional legality. And, in the 2000s, with the expansion of primary health care - which brings as principle social participation as an essential attribute in the shared responsibility of the health service and community of a health care committed to the local context and demands - culminated in the development of local health councils as promoters of these debates ${ }^{(3)}$.

Valuing the advances of social participation and aware that the involvement of the community and of the health sector still faces problems to consolidate, it is agreed with the study ${ }^{(4)}$ that emphasizes practices of abuse of authority, mainly over users, the low permeability as a deliberative instance to the detriment of advisory practice, demands centered on individual or corporate interests, and the deficient participation of health professionals who occupy a commissioned position. Does this impasse lead the counselor of the professional segment to an embarrassing position of voting against the government and in favor of health workers? Or in favor of the government and against the workers?

In this context, since the 1980s, there is a discussion on the perspective of the training of critical, reflexive professionals committed to their social role, who act as active subjects in their own life and work path and contribute to the construction of an egalitarian health system ${ }^{(5)}$.

Nursing is widespread in several spaces of production of individual and collective care, in health policies and services, and in local and municipal health councils, with the power to guide broader social changes ${ }^{(6)}$. Thus, studies that address the nurses' participation in movements of social policy and spaces of social participation, such as the municipal health councils, elucidate the contributions of great importance ${ }^{(1,3)}$.

\section{OBJECTIVE}

To deepen the perspective from the point of view of nurses who assumed the role of health counselors in order to understand at what point in their professional life there was the awakening to social control and its contributions to their practice in public health.

\section{METHOD}

\section{Ethical aspects}

The research was guided by Resolution No. 466 of December 12,2012 , of the National Council of Health/Ministry of Health on research involving human being ${ }^{(7)}$, which was approved by the Research Ethics Committee of State University Vale do Acaraú.

\section{Type of study}

The study is characterized by its exploratory-descriptive nature, with qualitative approach. This is based more on a reasoning led by an inductive process, which enables to explore and describe a reality or context and, finally, generate theoretical perspectives ${ }^{(8)}$.

\section{Methodological procedures}

Initially, in a visit to the Municipal Health Council (CMS) of Sobral (CE), we carried out a search in the appointment minutes for the 2008-2016 period to identify the counselors in the segment of health professionals with training in nursing.

The first contact with the professionals was through telephone and, on this occasion, was explained the purpose of the study and asked about the interest in participating. After they accepted the invitation, the interviews were scheduled as to time and place, according to the availability of the respondents.

The interviews were conducted from September to November 2016, when a meeting with the activists of the popular participation was allowed, to discuss the research topic. Participation in this study contributed to understanding the local context, broadening the comprehension of reality based on what the subject speaks, which provided the richness in the content analysis.

The data were collected after explanation of the Term of Free and Informed Consent by the researcher and after this document was signed by the research participant.

The whole conversation occurred face to face and followed the semi-structured interview guide, which contained three generating questions about the moment of interest in social participation, the challenges of the involvement with the health council, and the contributions from being a counselor to professional practice. This dialogue was recorded using a recorder, for later full transcription.

Participants were identified by the acronym $\mathrm{CN}$, referring to Counselor Nurse, added with ordinal numbers, according to the order of the interviews, namely: CN 1, CN 2, CN 3, CN 4, CN 5 , $\mathrm{CN} 6, \mathrm{CN} 7, \mathrm{CN} 8$, procedure that ensured the preservation of their anonymity.

\section{Study setting}

The research location was the municipality of Sobral, the main city in northwestern Ceará, located 238 kilometers from Fortaleza, with an area of approximately $2,123 \mathrm{~km}^{2}$ and a population of 212,718 inhabitants.

The municipality of Sobral (CE) has had the Municipal Health Council since 1993 , created by Municipal Law no. 52/1993(9), 
resulting from the municipalization process and the requirement for transfers of interfederative resources triggered by Organic Law of Health no. 8,142/90. Subsequently, it was amended in 2001 by Law no. 326, restructuring its composition, which became 24 (twenty-four) members, complying with the criterion of parity between providers, government and workers and users and respecting the following proportionality: $50 \%$ of users, $25 \%$ of health workers, and $25 \%$ of service providers and government.

\section{Data source}

The participant eligibility criteria were: having being or being health counselor in the city of Sobral, in the professional segment of health, in the periods 2008-2010; 2010-2012; 2012-2014; 2014-2016, and having a nursing degree.

Considering the criteria above, the population was nine individuals; however, of these, one refused to be involved in the investigation, totaling eight individuals to be investigated.

\section{Data organization and analysis}

After transcription of the interviews, the analysis was started, seeking to extract from the reports of participants significant data for the research. Data analysis followed six steps: 1) organization of data for analysis; 2 ) reading of all statements; 3 ) detailed analysis with coding process; 4) presentation of the themes extracted from the qualitative narrative; 5 ) extraction of meanings; and 6) development of thematic categories ${ }^{(10)}$, namely: "The awakening to social participation and control" and "Contributions from the participation as counselor to professional practice."

\section{RESULTS}

\section{The awakening to social participation and control}

According to the research participants, there is a gap between the interest in social control and academic life, in addition to being implied difficulties related to the historical context and domination of the State as to teaching and learning and their relations with social upheavals.

Never, at that time we didn't have it, we didn't think about that, you know, we didn't have the SUS. [...] That was my own thing, the training had nothing of participation, it was only technical, purely technical. [...] I was a professional of the Ministry of Health, the INAMPS [National Institute of Medical Assistance and Social Security], so I can make this comparison of how it was before and how it is now. (CN 1)

At the time I was in college it was very vague, the curriculum was very poor, I graduated in 1983. I believe, from what l've read, from what I've already lived, that what came from the family health is something new. (CN 3$)$

It is important to highlight that, in the reports of the participants, student movements (SM) have a significant role in the awakening of their interest in social control. There was unanimity among the participants in recognizing that it is within these movements that there is space for the first contacts with the recognition of social control as a way of improving the services provided.

In the mid academic period people ended up being directed to participation and militancy, but, to part of the student movements [...], that participating in student movements ends up, in fact, being involved in social movements. (CN 4)

I have always been involved in student movements, academic movements, movements of campaign groups, participating in these extra-academic movements, and it gradually strengthened the interest in social participation. (CN 7)

Although in a timid way, the student movement ended up finding a direction. (CN 2)

Participants also pointed out that entering the universe of Primary Health Care (PHC) within the scope of the Family Health Strategy (ESF) - whether as professional representing the category, indicated, or as co-founder of the CMS - was a moment that awakened their interest.

I started to get interested since I started working in Family Health, that there was the idea of forming the local health council in the units. (CN 5)

It emerged when I worked in the Primary Health Care of the city of Sobral, when I was manager of a Family Health Center and, at that time, as I worked in management, we had to encourage the population to social control, in the formation of local health councils. (CN 6)

\section{Contributions from the participation as counselor to professional practice}

The study participants report, with unanimity, personal and professional development, as well as a more critical and reflexive perspective concerning community issues, including a more humanized view after their participation in the CMS, in addition to expressing the strengthening of bonds and the need to actively listen to community requests.

I think it contributed to my development as a person. I think that this issue of participation contributed to expand my perspective, of the situation that people live, of knowing a reality that until then I was unaware of. (CN 1)

It only strengthened me, as to respecting the public opinion, feeling the real need and necessity of the community [...], you get closer to the community. I learned a lot, I think that, when we get out of the four walls of the office, out of the care of a Family Health Center, we experience the management and is able to better understand the processes, understand and comprehend the processes better, we can work better. So, that way I was able to perceive and understand the management of the SUS from those that are inside, then I got to know the difficulties, I got to know the problems that were there. (CN 5)

Beyond reflecting on the participation in the CMS as a facilitator of the "being manager," there is the comprehension of the 
community perception based on what is presented by popular entities whose approach to the community is more solid and brings a more effective perspective on the role of counselor.

The main contribution as a counselor, to my profession, was the improvement of the bond, we get closer to people, understand the user's vision that comes from their popular entities, which makes us rethink how we are working. (CN 8)

\section{DISCUSSIONS}

Based on the data of this research, it is possible to bring as a first focus the deficiency in the national scientific literature regarding the nurse within the Municipal Health Council, limiting the discussion of the results until reaching the reflection within a proposal of discussion with similar studies as occurred with the study on the characterization of nursing training in Colombia ${ }^{(11)}$. Nevertheless, we chose, here, to carry out the discussion in order to reflect on the findings of this study and, thus, to build evidence on the subject.

Based on the research findings, inferred from the participants' reports, it is possible to deduce that the interest in social control has little direct relationship with the academic training space, as there was no acknowledgement to this stage. Such gap may indicate discussions with little emphasis on the CMS that awaken in the academic students the interest in the subject, or even its absence within the political-pedagogical proposals of the programs to meet what was recommended by the National Curricular Guidelines of the Nursing Program regarding the social development of the nurse ${ }^{(12)}$.

Still in this perspective, if nurse training and development does not occur within the space of their initial training, this should be supplemented in the training processes of the counselor's activity, surpassing purely technical perspectives and awakening other dimensions of values ${ }^{(3)}$.

The deficiency in nurse training, considering the CMS, is no indication that this subject is not presented in nursing programs, but that it is little approached and that there is also a need to review the curricular issue of initial training, introducing the academic sphere to the context of social control - not only in the care focused on the health-disease process, still fixed in the biomedical vision. This perception of a training review implies the reordering of institutions as responsible in the training process so as to understand their responsibility for the curriculum that addresses the various dimensions for the challenges inherent in the Brazilian Unified Health System and in all its complexity, be that care, management, permanent education and social participation $^{(13-14)}$.

Worthy of note is the time reported by professionals spanning the period of military dictatorship, a regime in which the State exercised total authority over the population. There were no spaces for dialogue with the community and with the organized sectors of society, even banning the organization or expression of these sectors. During the dictatorial regime, the authoritarian State had strong control over the whole of society, a way that the ruling class found to exert its hegemony, supporting the consolidation of monopoly capitalism ${ }^{(15)}$.
It is also during the period of dictatorship that the Sanitary Reform is defended and, especially, the discussion about overcoming the private care model through the movements promoted by the social groups of both left-wing parties and intellectuals, who understood that the movement promoted by the people can reverse the control and domination relations that the State seeks to develop. Thus, it is up to the population in general to decide what the State should develop ${ }^{(15)}$.

The participants' statements indicate that nurses who follow the paths of municipal health councils are already from the health service, and that the participation is possibly associated with the indications that may happen by the labor classes and/or by the appointment of municipal administrators who have interest in maintaining representatives they trust ${ }^{(4,12)}$.

A study carried out in Teixeiras, in the Minas Gerais state, shows the negativity of political interventions in the space of CMS, also showing that this is also a perception of the members of the group. It is important to emphasize that legislation itself already indicates that $25 \%$ of CMS members should be representatives of the government sphere, which may give rise to a feeling of disbelief among council members ${ }^{(2)}$.

The way all research participants associate their participation in the CMS and their professional practice is another point to be highlighted in the findings of this study, when they mentioned improved bond with the community, closer relationship with the local reality, and understanding of the needs of the community. They also expressed the contribution as to the understanding of the structure and functioning of the SUS management and the process of building the care model focused on its principles and guidelines, an expanded understanding of health.

However, these are not the only aspects that should be observed. It should be noted that this perception of the importance of the bond with the community and the perspective of the problems enables the nurse - and now also a counselor - to be able to involve the community itself in observing and addressing its own problems ${ }^{(1)}$.

The counselor-nurses - and here is understood why the proposed title of this study - who had contact with the CMS in their professional lives focus not only on bureaucratic issues, but also on how they manage to be more humanistic based on their experiences. The nursing profession itself is already fraught with the symbolism of doing good, of health care, reinforced by the National Humanization Policy (PNH), which enables a comparison with the findings of the study carried out with HumanizaSUS supporters, in the perspective of learning with the work process ${ }^{(16)}$.

This salutary nursing practice, centrally focused on users and their needs, is what enables and fosters professional and personal growth, since the humanized view of the suffering of the other, heterogenizing instead of homogenizing ${ }^{(13)}$, should be part of nursing practice.

Thus, professionals should be involved in social control for planning and implementation of health actions, considering the broad dimension of this concept and the challenge that is presented, with the purpose of guaranteeing it, for the implementation of public policies and direct relationship with the user population, both in the individual and in the collective spheres, within a social, historical and cultural context that needs to be valued. 
The current context requires professional training that surpasses the merely technical practice and incorporates the management of social and public policies, ensuring a proactive professional, capable of meeting the health needs based on the SUS principles, in the instances of social participation and control.

\section{Study limitations}

Although the study obtained the participation of counselor nurses over ten years, the number of eight participants may have been insufficient to determine the contribution of the professional practice in the exercise of social control at the national level, considering that there is a need for more studies on the the same subject, with the purpose of capturing other realities, local specificities and the plurality of the Federation units.

\section{Contributions of the study}

However, the dialogue with counselor-nurses showed the extent to which academic training does not prioritize the reflexive discussion of social control, including beyond constitutional arrangements, coupled with an incipient culture of participatory democracy in the community, student, and professional life.

Discovering the counselor-nurse role is to know the dichotomy of producing and proposing transformations in health, sometimes having to oppose the vertical model proposed by the local administrator, who exercises authority over his or her employment.
It is necessary that social control occurs in practice so it is not only in law, and that civil society and health professionals occupy fully and effectively these spaces of social participation, to defend against and fight the opposing forces that want to perpetuate an unjust and unequal society.

\section{FINAL CONSIDERATIONS}

In a society that constantly reaffirms social rights, nursing has a social role in citizenship and in the daily process of reaffirming health as a right. Thus, it was observed that, by participating in health council, nurses obtains knowledge for personal and professional life, by means of their daily functions and training, becoming participatory professionals who have developed opinions and are aware of their rights and duties.

The representation of nurses as health counselors contributed to political and citizen involvement in consolidating the SUS, through planning, monitoring, and evaluation of health actions, since it was observed that being a counselor-nurse makes them more engaged in the social reality and in the principles of health.

It is up to the nurses to reflect on the proposal of a Health Council, having a triggering role to foster local health councils, in their territories of the Family Health Strategy, since it was proposed to be an instrument of legitimization of the SUS, representing a new way of thinking and acting to plan health policies. Thus, despite some deficiencies and misconceptions of nurses, we believe that nursing is on the right track in the defense and construction of a societal project.

\section{REFERENCES}

1. Oliveira DM, Deus NCP, Caçador BS, Silva EA, Garcia PPC, Jesus MCP. Nurses' knowledge and practice on social participation in health. Rev Bras Enferm [Internet]. 2016 [cited 2017 May 14];69(3):394-400. Available from: http://dx.doi.org/10.1590/0034-7167.2016690302i

2. Cotta RMM, Martins PC, Batista RS, Franceschinni SCC, Priori SE, Mendes FF. [Social control on the scene: reflecting on people's participation in the context of Health Councils. Physis [Internet]. 2011 [cited 2016 Oct 26];21(3):1121-37. Available from: http://dx.doi.org/10.1590/S010373312011000300019 Portuguese.

3. Souza TO, Silva JM, Nobrega SS, Constancio JF. [Social control: a challenge for the health counselor]. Rev Bras Enferm [Internet]. 2012 [cited 2017 Mar 10];65(2):215-21. Available from: http://www.scielo.br/pdf/reben/v65n2/v65n2a03.pdf Portuguese.

4. Zambon VD, Ogata MN. [Social control of the Single Health System: what think the municipal health counselors]. Rev Bras Enferm [Internet]. 2013 [cited 2017 May 14];66(6):921-7. Available from: http://dx.doi.org/10.1590/S0034-71672013000600017 Portuguese.

5. Martins ALX, Santos SMR. [Exercise of social control in Brazilian's National Health System: nurses' point of view as a member of local health Council]. Saude Soc [Internet]. 2012 [cited 2016 Dec 18];21(1):199-209. Available from: http://dx.doi.org/10.1590/S010412902012000500017 Portuguese.

6. David HMSL, Bonetti OP, Silva MRF. [Brazilian nursing and the democratization of health: notes on the National Policy of Popular Education in Health]. Rev Bras Enferm [Internet]. 2012 [cited 2016 Aug 12];65(1):179-85. Available from: http://www.scielo.br/pdf/reben/v65n1/26.pdf Portuguese.

7. Ministério da Saúde (BR), Conselho Nacional de Saúde. Resolução n. 466, de 12 de dezembro de 2012. Diretrizes e normas técnicas regulamentadoras de pesquisas envolvendo seres humanos. Diário Oficial da União: República Federativa do Brasil; 2012. Jul 13, Seção 1: p. 59. (col. 3).

8. Camara Municipal de Sobral (CE). Decreto n. 326, de 1 de outubro de 2001. Modifica a lei que dispõe sobre a criação do conselho municipal de saúde de sobral nas suas atribuições e composição (lei 52/93). Diário Oficial do Município de Sobral; 2001. Oct 2.

9. Sampieri RH, Collado CF, Lucio MPB. Metodologia de pesquisa. 5 ed. Porto Alegre: Penso; 2013.624 p.

10. Minayo MCS. O desafio do conhecimento: pesquisa qualitativa em saúde. 12. ed. São Paulo: Hucitec; 2010.407 p.

11. Borre-Ortiz YM, Pabon VY, Henao SL, Amaya BK, Polo TK. Caracterización de los programas de enfermería en Colombia. Investig Andina [Internet]. 2015 [cited 2017 May 25];17(31):1418-32. Available from: http://www.redalyc.org/articulo.oa?id=239040814011 
12. Colliselli L, Reibnitz, KS, Kleba ME, Comerlatto D. Conselho de saúde: uma reflexão sobre os processos de participação dos conselheiros. Rev Grifos [Internet]. 2012 [cited 2017 Apr 23];21(32-33):191-212. Available from: http://dx.doi.org/10.22295/grifos.v21i32/33.2408

13. Garcia Hernandez ML, Becerril LC, Gomez BA, Rojas AM, Ortega YH, Martinez, CS. [Emerging concept construction: professional nursing care]. Texto Contexto Enferm [Internet]. 2011 [cited 2017 Apr 10];20(Esp):74-80. Available from: http://dx.doi.org/10.1590/S010407072011000500009. Spanish.

14. Najera, RM. La asociación latinoamericana de escuelas y facultades de enfermería y sua portación a la docencia, la investigación y la práctica em enfermería. Rev Iberoam Educ Invest Enferm [Internet]. 2011 [cited 2017 Mar 19];1(1):12-6. Available from: http://www.enfermeria21. com/revistas/aladefe/articulo/3/

15. Bravo MIS, Correia MVC. [Challenges of the social control nowadays]. Rev Serv Soc [Internet]. 2012 [cited 2017 Apr 22];109:126-150. Available from: http://dx.doi.org/10.1590/S0101-66282012000100008 Portuguese.

16. Martins CP, Luzio CA. HumanizaSUS policy: anchoring a ship in space. Interface Comun Saúde Educ. [Internet]. 2017 [cited 2017 Apr 22];21(60):13-22. Available from: http://dx.doi.org/10.1590/1807-57622015.0614 